\title{
Double purpose wheat: correlation analysis of forage yield components
}

\author{
Alicia Morant, Héctor Merchán, and Eugenio Lutz \\ Departamento de Agronomía, Universidad Nacional del Sur. San Andrés 800 - B Palihue (8000) Bahía \\ Blanca, Buenos Aires, Argentina.
}

\begin{abstract}
A. Morant, H. Merchán, and E. Lutz. 2010. Double purpose wheat: correlation analysis of forage yield components. Cien. Inv. Agr. 37(1): 55- 61. The direct and relative contribution of characters associated with forage production were evaluated in a comparative assay of wheat cultivars to contribute to an ideotype definition when selecting double purpose material for forage and grain production. Simple correlations for all of the possible combinations among the measured variables were calculated. The correlation partition method, known as path coefficient, was applied to determine the causes of this association and to measure the relative importance of each factor. Forage production during the vegetative period was measured for each variety at the dates in which the apex reached the double ridge state (3 - 4 in the Nerson scale). The double ridge state was considered the deadline of the vegetative primordial production. Tiller numbers, live leaf numbers, dead leaf numbers, total leaf numbers and yield components in the forage were measured simultaneously. These variables had values of correlation, high positive and significant $(\mathrm{p} \leq 0.01)$ with variable dry weight, and largely explained $\left(\mathrm{R}^{2}=0.963\right)$ forage yields of the cultivars. Standard partial regression analyses indicated that the variables that most contributed to forage production were the total leaf and tiller number. Under these criteria, the ProINTA Pincen and ProINTA Super cultivars that had the highest dry weight values should meet the required conditions to adapt to dual purpose production.
\end{abstract}

Key words: Correlation, forage yield, path coefficient analysis, Triticum, yield components, wheat.

\section{Introduction}

Crop productivity depends on numerous interactions continuously through the life cycle of the crop, such as genotypes, environmental conditions and cultural management. Any attempt to identify the physiological bases of features, such as yield, begins from the recognition of the complexity of these interactions (Hall, 1980). A large number of genes are involved in determining the final yield, even some that ap-

Received 25 March 2009. Accepted 14 May 2009.

Corresponding author: amorant@criba.edu.ar parently do not contribute to it (von der Pahlen, 1980). The basic ideotype, as defined by Donald (1968) to be the morphological type to render the maximal production in a specific environment, must be progressively modified according to environmental changes or management practices. Several complex features have responses to the selection that depends on low heritability. Sometimes for greater ease of measurement, have higher heritabilities or explain through what strategies the ground floor achieves better performance.

From the predictive point of view of the selection result in a program of genetic improvement, 
it is important to know how an attribute of the yield component is modified when another correlated attribute is selected. This is especially important if the correlations are negative, which may neutralize the effort made by the improvement. To have real utility, a high correlation must exist between the variables measured and the final product.

Plant breeders have tried to manage features of simple heredity with a high response to the selection through the study of the yield components in grain (von der Pahlen, 1980). The components that are related to yield do not always result with an efficient selection (Mariotti, 1986). Neither of the correlations should be considered conclusive (Hiorth, 1985), as they may vary according to their origin (linkage or pleiotropy) by the inter-component interactions (positive or negative) or changes in the variability by effects of the selection.

The analysis of the correlation ( $\mathrm{Li}, 1956)$, path coefficient (Wrigth, 1923) or partial standard regression coefficient (Snedecor and Cochran, 1978) partition the coefficient of total correlation relative to direct and indirect effects from each component based on the variations of the dependent complex feature. The method, based on the hypothesis of causal relations in a system of correlated variables, measures the relevance of a specific form of the cause to the effect. The direct effect is an absolute number that is independent of the units of measurement used for the variables, which measures the effect of each component independently of its interactions with the other factors of the system that are considered.

This method was widely used by animal breeders and geneticists and, to a lesser extent, by plant breeders, although only some of them consider the yield in seeds as the yield in forage (Dewey and Lu, 1959; Liang and Riedl, 1964; Bhamonchant and Paterson, 1964; Martín et al.,1971; Martinez et al., 1970; Martín and Salvioli, 1971a and 1971b; Pe and Camussi, 1982; Hampton and Hebblethwaite, 1983; Undesander, 1987; Carvalho et al., 2001; Gonçalves et al., 2003; Abbott et al., 2007). There is abun- dant literature pertaining to wheat yield, but the literature refers mainly to the components of grain yield as the main objective of selection (Adams, 1967; Miranda et al., 1996; Parodi et al., 1970; Zamora Villa et al., 2004). The yield components are affected by climate and different agronomic management techniques, such as defoliation, fertilization or irrigation. Any of these techniques may have positive, null or negative effects depending on the time and the intensity to which they are used. These practices may produce a set of compensating effects that hide the responses to their individual applications, which may confuse the results (Adams and Graffius, 1971; Hill and Watkin, 1975; Arias and Bertín, 1986).

In addition, if simultaneous improvements in forage, seed or grain productions are intended to be completed, it is necessary that the selection be effective for all cases. Therefore, it is useful to know the interrelation between the features involved. Using a simple correlation and path coefficient method, the cause and effect relationship between yield and associated features and the relative importance of each will be known according to their influence on forage and grain yield (Liang and Riedl, 1964).

The direct and relative contribution from features associated with wheat (Triticum sp.) yield forage was assessed in the present work to characterize an ideotype to be used by selection for a double purpose use in a specific environment.

\section{Materials and methods}

The study was conducted in the experimental field of the Departamento de Agronomía, Universidad Nacional del Sur, Bahía Blanca (38 11 '10" latitude S; 62 $10^{\circ} 11$ ' longitude W; 83 above see level). The experimental field consisted of sandy soil with tuff stone underneath, causing the field to be highly susceptible to erosion, and the field had a low capacity for water retention and low organic matter content (Sanchez and Kruger, 1981, unpublished data). The meteorological conditions that were present in the period of the study are shown in Table 1 . 
Table 1. Meteorological information for 1996 obtained from the Agrometeorology Station Altos de Palihue.

\begin{tabular}{lrrrrrrrrrrrr}
\hline \multicolumn{1}{c}{ Parameters } & \multicolumn{1}{c}{ Jan } & \multicolumn{1}{c}{ Feb } & Mar & Apr & May & Jun & Jul & Aug & Sept & Oct & Nov & Dec \\
\hline Mean temperature ${ }^{\circ} \mathrm{C}$ & 22.3 & 21.2 & 21.0 & 14.8 & 12.3 & 7.5 & 7.6 & 11.7 & 12.1 & 15.8 & 20.7 & 20.6 \\
Rainfall, mm & 46.4 & 50.6 & 19.8 & 64.0 & 48.4 & 9.4 & 12.6 & 66.8 & 6.6 & 43.8 & 22.0 & 145.2 \\
$\sum$ temp,${ }^{\circ} \mathrm{Cd}$ & 899.7 & 773.2 & 769.8 & 525.7 & 507.3 & 280.5 & 286.5 & 435.0 & 435.3 & 647.6 & 777.8 & 968.0 \\
Cold hours $^{2}$ & 3.0 & 6.5 & 1.5 & 80.5 & 172.0 & 372.0 & 366.5 & 206.5 & 193.5 & 53.0 & 22.5 & 0.0 \\
\hline${ }^{1}$ Lindsey and Newman method, basal temperature $=0{ }^{\circ} \mathrm{C} ;$ & & & & & & & & \\
${ }^{2}$ Estimated $\leq 7{ }^{\circ} \mathrm{C}$. & & & & & & & & & &
\end{tabular}

The experiment was carried out in dry land conditions with plots containing seven lines ( $2 \mathrm{~m}$ long and separated by $20 \mathrm{~cm}$ ) that were arranged according to a randomized complete block design with five repetitions.

Ten commercial wheat cultivars that were considered as having a long cycle were used: ProINTA Pincén, ProINTA Super, ProINTA Pigüé, Buck Charrúa, Buck Poncho, Buck Catriel, Cooperación Maipún, Cooperación Liquén, Cooperación Nanihué and Klein Cacique.

The harvest was completed on April 9, 1996 with a density of 250 seeds per $\mathrm{m}^{2}$ after a broadcast fertilization with urea in an $80 \mathrm{~kg} /$ ha ratio. Weeds were manually controlled.

The apex passage to the reproductive double ridge stage was controlled at six day intervals from the three-leaf stage ( 3 - 4 stage according to the Nerson scale) (Nerson et al., 1980). The measurement of the variables was made for each cultivar on the date when the apex reached the double stage, which is the limit for last grazing without harming the grain production (Krenzer, 1995; Lutz et al., 2000) and indicates the end of the vegetative primordia production (Slafer and Rawson, 1994; Miralles and Slafer, 1999). The dead and total number of tillers and the number of live leaves were determined. The numbers were determined by components of yield forage of five individual plants, and these values were considered as an estimation of the forage production during the vegetative period. The dry weight of the plants was measured after drying the aerial portion without roots in a stove at $65^{\circ} \mathrm{C}$. The period of data collection extended until August 3,1996 , when the double ridge stage was ob- served in the latest variety (Nerson et al., 1980). The variability of the features measured was analyzed by an analysis of variance (ANOVA) followed by Tukey's multiple comparison test ( $p$ $<0.01$ ) as previously described (Morant et al., 2007). Subsequently, the calculation of the coefficient of simple correlation (r) was conducted with this information for all possible combinations among the variables measured from all of the tested cultivars. Taking into account the statistical significance between pairs of features, the model of causal relations was determined based on the correlation matrix with the variables that had a significant correlation with dry weight.

The relative direct and indirect effects of the postulated causes were analyzed by the correlation partition by the path or trajectory coefficient method, and the equation of multiple correlations was formulated for the estimation of dry weight. This equation established the determination coefficient $\left(\mathrm{R}^{2}\right)$ that indicated the incidence percentage of the variables considered as a whole.

The wheat cultivars with the highest values of dry weight were considered individually, and the same procedure was applied to test if the behavior matched the general results or if they had different strategies of forage production.

\section{Results and discussion}

The forage yield represents an attribute depending on a certain number of other variables. The amount of dry matter per plant that was accumulated during the vegetative period was es- 
timated for each variety using an equation for multiple correlations of estimation. This equation was composed of the number of tillers, total leaves, live leaves and dead leaves per plant. The variables had high positive and significant values of simple correlation $(p<0.01)$ in the conditions of the test (Table 2). coefficient (obtained by the statistical MSTAT Program from the University of Michigan).

When the partition results were analyzed with the respective coefficients of simple correlation, the number of total leaves had a relative importance with the highest influence, but the

Table 2. Total correlation and standard correlation coefficients between yield and dry weight components (dependent variable).

\begin{tabular}{|c|c|c|c|c|c|c|}
\hline \multirow[b]{2}{*}{ Variables } & \multicolumn{4}{|c|}{ Simple Correlations Matrix between variables } & \multirow[b]{2}{*}{$\begin{array}{l}\text { Dry weight total } \\
\text { correlation }\end{array}$} & \multirow[b]{2}{*}{$\begin{array}{l}\text { Standard partial re- } \\
\text { gression coefficient }\end{array}$} \\
\hline & $\begin{array}{c}\text { Tillers } \\
\text { no.plant }{ }^{-1}\end{array}$ & $\begin{array}{c}\text { Total } \\
\text { leaves } \\
\text { no.plant }{ }^{-1}\end{array}$ & $\begin{array}{l}\text { Living leaves } \\
\text { no.plant }^{-1}\end{array}$ & $\begin{array}{c}\text { Dead leaves } \\
\text { no.plant }^{-1}\end{array}$ & & \\
\hline Tillers, no.plant ${ }^{-1}$ & 1.000 & 0.976 & 0.940 & 0.855 & 0.947 & -0.192 \\
\hline Total leaves, no.plant ${ }^{-1}$ & 0.976 & 1.000 & 0.967 & 0.874 & 0.971 & 10.94 \\
\hline Living leaves, no.plant ${ }^{-1}$ & 0.940 & 0.967 & 1.000 & 0.721 & 0.930 & -6.889 \\
\hline Dead leaves, no.plant ${ }^{-1}$ & 0.855 & 0.874 & 0.721 & 1.000 & 0.860 & -3.572 \\
\hline
\end{tabular}

The variables considered are interrelated. Therefore, each variable influenced the dry weight (Y) through their direct contribution (Pi) and indirectly combined with the other variables, as follows: $\mathrm{Y}=24.102 \mathrm{X}_{1}+410.01 \mathrm{X}_{2}$ $-367.89 \mathrm{X}_{3}-370.79 \mathrm{X}_{4}+98.67889$, where $\mathrm{X}_{1}=$ number of tillers, $\mathrm{X}_{2}=$ number of total leaves, $\mathrm{X}_{3}=$ number of live leaves and $\mathrm{X}_{4}=$ number of dead leaves.

The high value reached by the determination coefficient $\left(\mathrm{R}^{2}=0.963\right)$ indicated that the variables considered explained the yields of this group of cultivars to a large extent where only $3.7 \%$ was attributable to effects of unexpected variables in the model $\left(\mathrm{Pn}=1-\mathrm{R}^{2}=0.1923\right)$.

The nature of the causal system is shown by a diagram in Figure 1 where the double arrows indicate a mutual association mediated by coefficients of correlation and the simple arrows represent direct influences measured by the path direct effect of the number of tillers was lower than what their coefficient of total correlation implied.

The Pincén and Super cultivars, from which the highest values of dry weight were obtained, were analyzed separately, and the same procedure was applied The direct effect of the decrease in the tiller number was also shown to be important in these important cultivars (Table 3).

For the indicated conditions of the test, the correlation partition of the test variables that contributed more to the forage production were the number of total leaves and number of tillers. This data suggested the number of total leaves and tillers should be used as selection criteria. The biological contradiction involved in the number of tillers may have a low influence as a component of forage production and may be explained by the heterogeneity in the tiller size. 


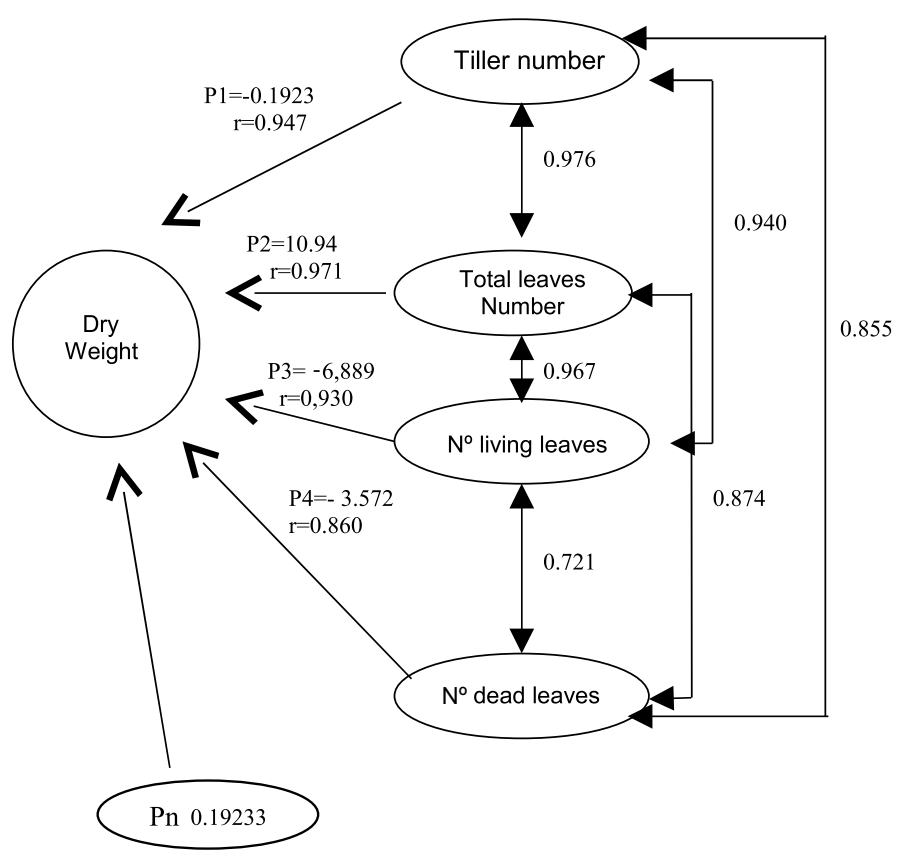

Figure 1. Simple correlation partition diagram for dry matter components in wheat is shown. $\mathrm{r}=$ correlation coefficient and $\mathrm{Pi}=$ standard partial regression coefficient (direct effect).

In addition to number of tillers, the determination of their weight or size is suggested as being influential. Therefore, this variable should not be discarded until a more complete study can be done to attempt an increase of the forage yield by methods of indirect selection.

According to this study, the ProINTA Pincén and ProINTA Super cultivars produced the highest values of dry weight, and they had conditions to adapt for the have conditions to suit the application with a dual purpose.

\section{Acknowledgements}

The present work was financed by the Secretary of Science and Technology of Universidad Nacional del Sur, Bahía Blanca, Argentina.

Table 3. Total correlation and standard correlation coefficients between dry weight forage yields and its components for the ProINTA Super and ProINTA Pince wheat cultivars, compared with the totals for wheat cultivars is shown.

\begin{tabular}{|c|c|c|c|c|}
\hline Variables & $\begin{array}{l}\text { Dry weight } \\
\text { total correlation }\end{array}$ & $\begin{array}{l}\text { Standard partial regression } \\
\text { coefficient } \\
\text { (Total) }\end{array}$ & $\begin{array}{l}\text { Standard partial regression } \\
\text { coefficient } \\
\text { (cultivar Pincén) }\end{array}$ & $\begin{array}{l}\text { Standard partial regression } \\
\text { coefficient (cultivar Super) }\end{array}$ \\
\hline Tillers, no.plant ${ }^{-1}$ & 0.947 & -0.192 & 0.2607 & 0.06739 \\
\hline Total leaves, no.plant ${ }^{-1}$ & 0.971 & 10.94 & 7.116 & 4.385 \\
\hline Living leaves, no.plant ${ }^{-1}$ & 0.930 & -6.889 & -5.894 & -3.243 \\
\hline Dead leaves, no.plant ${ }^{-1}$ & 0.860 & -3.572 & -1.596 & -3.097 \\
\hline
\end{tabular}




\title{
Resumen
}

\begin{abstract}
A. Morant, H. Merchán y E. Lutz. 2010. Trigo de doble propósito. Análisis de la correlación entre componentes de rendimiento forrajero. Cien. Inv. Agr. 37(1): 55 - 61. Con datos obtenidos de un ensayo comparativo de diez cultivares de trigo se evaluó la contribución directa y relativa de caracteres asociados con el rendimiento forrajero, con el propósito de contribuir a la definición de un ideotipo para selección de genotipos para doble propósito (producción de pasto y grano). Se calcularon las correlaciones simples para todas las combinaciones posibles entre las variables medidas y se particionaron luego por el método del Coeficiente de Sendero, para determinar las causas de esta asociación y establecer la importancia relativa de cada factor. La cantidad de materia seca acumulada durante el período vegetativo se estimó para cada variedad como Peso Seco de la planta en la fecha en que el ápice alcanzó el estado de doble arruga (3-4 en la escala de Nerson), momento límite para la producción de primordios vegetativos. En el mismo momento se determinaron las variables: Número de Macollos, de Hojas Vivas, Muertas y Totales, considerados componentes del rendimiento en forraje. Dichas variables tuvieron valores de correlación, altos, positivos y significativos $(\mathrm{P} \leq 0,01)$ con la variable Peso Seco, y explicaron en gran medida $\left(\mathrm{R}^{2}=0,963\right)$ los rendimientos de forraje de los cultivares. La partición de la correlación indicó que, para las condiciones del ensayo, las variables que más aportaron a la producción de forraje fueron Número de Hojas Totales y Número de Macollos. Con este criterio, los cultivares ProINTA Pincén y ProINTA Super, con los cuales se obtuvieron los mayores valores de Peso Seco, tendrían condiciones para adaptarse al uso con doble propósito.
\end{abstract}

Palabras clave: Coeficiente de sendero, componentes de rendimiento, correlación, rendimiento de forraje, trigo, Triticum.

\section{References}

Abbott, L. A., S. M. Pistorale, and O. S. Filippini 2007. Análisis de coeficientes de sendero para el rendimiento de semillas en Bromus catharticus. Cien. Inv. Agr. 34:141-149.

Adams, M.W. 1967. Basis of yield component compensation in crop plants with special reference to the field bean, Phaseolus vulgaris. Crop Science 7:505-510.

Adams, M.W., and J.L. Graffius. 1971. Yield components compensation - alternative interpretations. Crop Science 11:33-35.

Arias, J.E., and O.D Bertín. 1986. Los componentes de rendimiento en la producción de semillas forrajeras. INTA Pergamino Información General $\mathrm{N}^{\circ} 140: 1-3$.

Bhamonchant, P., and F.L. Paterson. 1964. Association of morphological characters and lodging resistance in a cross involving milford type oats. Crop Sci. 4:48-51.

Carvalho, C. G. P. de, R. Borsato, C. D. Cruz, and J. M. S. Viana. 2001. Path analysis under multicol- linearity in S0 x S0 maize hybrids. Crop Breeding and Applied Biotechnology 1:263-270.

Dewey, D.R., and K.H. Lu. 1959. A correlation and path-coefficient analysis of components of crested wheatgrass seed production. Agronomy Journal 51:515-518.

Donald, C.M. 1968. The breeding of crop ideotypes. Euphytica 17:385-403.

Gonçalves, M. C., A. M. Correa D. Destro, L.C. Ferreira de Souza, and T. Alves Sobrinho. 2003. Correlations and path analysis of common bean grain yield and its primary components. Crop Breeding and Applied Biotechnology 3:217-222.

Hall, A. J. 1980. Los componentes fisiológicos del rendimiento de los cultivos. Revista de la Facultad de Agronomía, Universidad de Buenos Aires, Argentina 1:73-86.

Hampton, J.G., and P.D. Hebblethwaite. 1983. Yield components of the perennial ryegrass (Lolium perenne L.) seed crop. J. Appl. Seed Prod. 1:23-25.

Hill, M.J., and B.R. Watkin. 1975. Seed production studies on perennial ryegrass, timothy and praire grass. 1. Effect of tiller age on tiller survival, ear emergence and seedhead components. Journal of 
British Grassland Society 30:63-71.

Hiorth, G.E. 1985. Genética Cuantitativa. I: Fundamentos Biológicos. Ed. Universidad Nacional de Córdoba, Argentina. Cap. 9:264-296.

Krenzer, G.1995. Management practices and net returns in a wheat-stocker enterprise. Production Technology - Crops Oklahoma Cooperative Extension Service 7:1-5.

Li, C.C. 1956. The concept of path-coefficient and its impact on populations genetics. Biometrics 12:190-210.

Liang, G.H.L., and W.A. Rield. 1964. Agronomic traits influencing forage and seed yield in alfalfa. Crop Science 4:394-396.

Lindsey, A. A., and J. E., Newman. 1956. Use of official weather data in spring time-temperature analysis of an Indiana phenological record. Ecology $37: 812-823$.

Lutz, E.E., H.D. Merchán, and A.E. Morant. 2000. Estado de desarrollo de la planta de trigo (var. ProINTA Pincén) al momento de la última defoliación y su rendimiento en grano. Phyton 68:8387.

Mariotti, J.A. 1986. Fundamentos de Genética Biométrica. Aplicaciones al Mejoramiento Genético Vegetal. Colección de Monografías Científicas $\mathrm{N}^{\circ}$ 32. OEA, Programa Regional de Desarrollo Científico y Tecnológico. Washington, D.C. 149 pp.

Martín, G.O., and R.L.A. Salvioli. 1971a. Estudio de la asociación entre componentes de rendimiento e índice de selección en maíz (Zea mays L.). Revista Agronómica del N.O. Argentino 8:391-410.

Martín, G.O., and R.L.A. Salvioli. 1971b. Determinación del efecto directo relativo de los componentes del rendimiento en maíz (Zea mays L.). Revista Agronómica del N.O. Argentino 8:435450.

Martín, G.O., R.L.A. Salvioli, N. Guyot, and C.A. Rovella. 1971. Interacción de caracteres agronómicos y variabilidad de una población de pasto crespo (Trichloris pluriflora Fourn.). Revista Agronómica del N.O. Argentino 8:543-555.

Martínez, W.O., M. Ríos, D. Leal, H. Azuero, and C. M. Torregrosa. 1970. Asociaciones fenotípicas entre componentes de rendimiento en maíces de clima frío. II Estudio sobre regresiones. Revista del Instituto Colombiano Agropecuario 5:65-76.

Miralles, D.J., and G.A. Slafer. 1999. Wheat development. Wheat. Ecology and Physiology of Yield Determination. E.H. Satorre and G.A. Slafer (ed.).
Food Product Press. New York. p. 13-43.

Miranda, R., A.E. Morant, A.A. Junquera, and S.C. Borsetti. 1996. Yield components in semi-arid environments of Argentina. $5^{\text {th }}$ International Wheat Conference, Ankara, Turkey:54-55.

Morant, A.E., H.D. Merchán, and E.E. Lutz. 2007. Características forrajeras de trigos para doble propósito. Phyton 76:96-102.

Nerson, H., M. Sibony, and M. J. Pinthus, 1980. A scale for the assessment of the developmental stages of the wheat (Triticum aestivum L.) spike. Annals of Botany 45:203-204.

Paccapelo, H.A., and H.O. Lorda. 1988. Determinación de los efectos relativos directos e indirectos de los componentes sobre el rendimiento de trigo. Revista de la Facultad de Agronomía de la Pampa 3-2:1-14.

Parodi, P.C., FL. Patterson, and W.E. Nyquist. 1970. Interrelaciones entre los componentes principales y secundarios de rendimiento en trigo, Triticum estivum L. Fitotecnia Latinoamericana 7:1-15.

Pe, E., and A. Camussi. 1982. Yield components and plant traits in summer-sowing maize. Maydica 27:169-183.

Sánchez, L.F., and H.R. Kruger. 1981. Los suelos del campo Palíhue de la Universidad Nacional del Sur. 10 pp.

Slafer, G.A., and H.M. Rawson. 1994. Sensitivity of wheat phasic development to major environmental factors: a re-examination of some assumptions made by physiologists and modellers. Aust. J. Plant Physiol. 21:393-426.

Snedecor, G.W., and W.G. Cochran. 1978. Métodos estadísticos. J.A. Reinosa Fuller (Trad.). Quinta impression. Compañía Editorial Continental S.A. México. 703 pp.

Undesander, D.J. 1987. Yield and yield component response of maize to water stress in hybrids with different sources of stress tolerance. Maydica 27:49-60.

von der Pahlen, A. 1980. El control genético de los componentes de rendimiento. Revista de la Facultad de Agronomía EFA, Universidad de Buenos Aires 1:87-96.

Wrigth, S. 1923. The theory of path coefficients. Genetics 8:239-255.

Zamora Villa, V M., A. J. Lozano del Río, M. Colín Rico, and M. A. Torres Tapia. 2004. Análisis de sendero en trigos de distintos hábitos con y sin restricción de humedad. http://www.uaaan.mx 
